\title{
Prick Lit or Naked Hope? Self-exposure in Hanif Kureishi's Intimacy
}

\begin{abstract}
Hanif Kureishi's works contain numerous autobiographical features and are peopled with characters that often bear a striking similarity not only to the author himself but also to his relatives and ex-partners. Intimacy (1998) is conceived as the dramatic confessional monologue of a middle-aged man about to leave his partner and two children to live with a younger woman, an experience the author himself had not long before its publication. This article deals with the novella in the broader context of the author's late 1990s texts in order to distinguish between autobiographic narrative and writing from experience, showing that the latter rather than the former is employed in these works. Supported by Kureishi's defence of the book as a literary game it also argues that rather than providing a hateful perspective on femininity the novella offers a variation on one of the author's idiosyncrasies - a hopeful belief in love and humanity. The article further attempts to explore the possibilities and limitations of the genre of confessional narrative as exemplified in Intimacy.
\end{abstract}

\section{Key words}

Hanif Kureishi; Intimacy; autobiography; writing from experience; mid-life crisis; masculinity; alienation effect

From his early screenplays to his latest novel so far, Something to Tell You (2008), Hanif Kureishi has always drawn extensively from his own life experience. His works are peopled with characters that often bear a striking similarity not only to the author himself but, mostly to their dislike, to his various relatives, friends and ex-partners. Unlike the memoir, My Ear at His Heart (2004), which met with little seriously outraged protest, Kureishi's other works do not aspire towards autobiographic writing, but to imaginative fiction; the characters never appear as plausible and authentic reflections of real personages but possess only 
some of their features or character traits. It should be noted that these are mostly comic, further exaggerated into caricature in order to serve a desired function in the story's overall narrative framework. Therefore, it is understandable that these works have aroused negative reactions from those who felt abused or even denigrated by having been unfaithfully portrayed and misrepresented and that Kureishi has had to face up to claims that he has exploited these people selfishly, making them "fabricated for the entertainment of the public and for [his] profit" (Yasmin Kureishi 2008).

The most outspoken and indignant of these voices is that of Kureishi's sister, Yasmin Kureishi, who has repeatedly accused her brother in the press of his deliberate exploitation of family members and intimate friends in his writing, namely the parents in The Buddha of Suburbia (1990), with Yasmin claiming that their father, feeling robbed of his dignity, did not speak to Hanif for a year; uncle Omar in My Beautiful Laundrette (1996); an ex-girlfriend, Sally, in Sammy and Rosie Get Laid (1988), who mockingly renamed it as "Hanif Gets Paid, Sally Gets Exploited"; an ex-partner and the mother of his two children, Tracey Scoffield, in Intimacy (1998); and herself, portrayed spitefully as an insipid, two-dimensional character in the film The Mother (2003) (ironically enough, Scoffield was the producer of the BBC film) (Yasmin Kureishi 2008). In her latest article, published after the release of Something to Tell You (2008), Yasmin Kureishi expresses her sarcastic relief that the main protagonist's sister was not based on her but another family member, calling this tendency of her brother's fictions an "abuse of privilege" (2008). Yet she goes even further, suggesting that the fact that the book centres on psychoanalysis stems from the author's own need to be analysed, because of his unresolved childhood sibling-rivalry issues that account for his "hatred" for his sister, which inspired his intimidating media statements. According to her, this eventually transformed into Hanif's jealousy of Yasmin's talent as a writer, another claim that Kureishi resolutely dismisses as a figment of her imagination. It is impossible to judge who is right but this brief account of the argumentation shows the particular atmosphere surrounding the publication and reception of Kureishi's works.

Intimacy occupies a specific position in this context as it can, on one level, be read as a highly controversial semi-autobiographical novella inspired by Kureishi's recent experience of leaving his partner and two children to live with a younger woman. The novella was immediately met with a storm of critical opinion (ironically, female reviewers were more forbearing that their male colleagues), accusing the author of callousness, vindictiveness and misogyny, and portraying him as a "heartless and irresponsible philanderer" and taking the book as a "defensive manoeuvre designed to win public sympathy" (Buchanan 2007: 36). Scoffield immediately confirmed that the book did depict their relationship and accused it of "total hypocrisy" which can by no means be called art as "you may as well call it a fish" (qtd. in Thomas 2005: 140). Despite the author's efforts to defend the work's artistic value and legitimacy, only a few critics and scholars have found it worthy of praise. The aim of this article is to show that reading the 
novella merely as a malicious and vengeful account of Kureishi's breakup, aimed at denigrating a former partner and attacking women in general, is simplistic, reducing the text to a purely personal level and by doing so ignores its undeniable literary value. It also argues that, despite its gloomy tone, rather than providing a hateful perspective on femininity the novel offers a variation on one of the author's idiosyncrasies - a hopeful belief in love and humanity.

\section{The Chronicler of Mid-Life Crisis}

In the late 1990s, Kureishi's literary career entered a new phase in which his writing partly or completely abandoned the major thematic concerns of his previous works - ethnicity, racism, politics and the formation of identity in the process of finding a position in society - in favour of a more private and introspective narrative perspective focusing on the ideas, feelings, anxieties and obsessions of the predominantly male characters. As the author was nearing his mid-forties, his main protagonists tend to be men of this age, suffering from what is commonly termed the male mid-life crisis: they all feel emotionally and sexually "suffocated" in their marriage or long-term relationships and so they leave their wives, partners and children, in order to regain happiness by re-establishing their former selves, which they believe they have somehow lost in the passionless and dull domesticity of family life. Although these works represent a distinctive turning point in Kureishi's writing, they also develop, though in a more serious manner, some of his characteristic themes and motifs, such as the family, sexuality, popular culture and drug abuse. The shift from the public to the personal is most reflected in the tone of the narratives which, marked by a transformation from the light-hearted yet thoughtful human comedy to the at times laboured, in-depth narrative scrutiny of middle-aged men's traumas, becomes markedly less optimistic.

This specific period of Kureishi's career is marked by three books; the short story collections, Love in a Blue Time (1997) and Midnight All Day (1999), and the novella Intimacy, which are thematically so affined that it is in fact possible to treat them as a whole. His two following works, Gabriel's Gift (2001) and The Body (2002), can be said to already signal a new tendency in his writing; although they deal with the same interrelated themes they differ in both spirit and tone. The former offers a cheerfully optimistic or even redemptive solution to the dilemmas the three immediate predecessors find virtually irresolvable - Kureishi makes his middle-aged character, who, moreover, is not the story's central protagonist as the author once more employs a youthful hero, contemplate the losses and mournful prospects resulting from the abandonment of his family and even return and marry the mother of his son. The Body, even though it starts as another introspective account of the miseries of ageing, develops into a satirical view of the vanities, delusions and misconceptions of the longing for never-ending youth and its pleasures. The protagonist cherishes the enjoyments of mature love and life experience and, in consequence, realises that the familial and familiar do not necessarily need to 
be dull and dreary, or make him feel confined in a strange body, "condemned to begin again, in the nightmare of eternal life" (Kureishi 2002: 126).

The short story collections can be read, respectively, as Intimacy's thematic and discursive harbinger and sequel. The stories in Love in a Blue Time introduce Kureishi's new subject matter - how does a passionate and spirited man enter middle age? The main critique is focused on the institution of marriage (or familial domesticity) and the idea of happiness achieved through the stockpiling of middle-class certainties and material goods. Marriage is portrayed as a stereotyped, mundane, conventional social arrangement, lacking intensity and affection, and Kureishi's male characters, feeling stuck in this backwater, struggle to set themselves free from its bonds through short-lived love affairs or by leaving their wives for new partners. In the story "D' accord, Baby," Bill explains that "infidelities would occur in most relationships. [...] And why not, when marriage was insufficient to satisfy most human need?" (Kureishi 1999a: 54); in "Nightlight," the anonymous male protagonist observes that London abounds with people leaving their partners for others, calling it a "city of love vampires, turning from person to person, hunting the one who will make the difference" (Kureishi 1999a: 142). The problem is that no new relationship seems to make any difference as it always, after some time, falls into the same routine of housekeeping and childcare, which makes a collapse unavoidable. In the last story of the collection, "The Flies," a gloomy magic-realistic parable of matrimony, Baxter, the husband, having tried all he could to invigorate and thus save the marriage, notes with resignation that "nothing can be repaired or advanced but only accepted" (Kureishi 1999a: 210). When Baxter is considering leaving his wife, he realises how difficult this "inevitability" in fact is: "Without thinking, he gave her his life. He valued it less then, and now he wants it back. But he knows that retrieving a life takes a different courage, and is crueler" (Kureishi 1999a: 201). Symbolically enough, the story ends with Baxter and other men like him wandering determinedly yet without direction in the darkness of the night, searching, if not for a better future, then at least for the courage and cruelty to terminate the painful present.

Although Midnight All Day continues the theme of the problems of partnerships and cohabitation, it offers a more soothing perspective and more conciliatory tone than the two preceding works. The protagonists, middle-aged men who have left their wives and are now living with their new partners with whom they already have a child or are expecting one, are striving to accommodate themselves in their new familial arrangements. Unlike their predecessors from Love in a Blue Time, they seem to be aware that happiness in life is a matter of the right choice of partner, and once this choice is made it is their responsibility to make the relationship work. The story of "Four Blue Chairs" climaxes in the farcical scene in which John is desperately struggling to carry the four new chairs to the nearest underground station, which he sees as a metaphor for his new relationship with the much younger Dina. Yet he does not complain as he knows too well that he has what he wished for: "He knows that this is part of the new life he has longed for, and at these times he feels helpless. He can't afford to have it 
go wrong" (Kureishi 1999b: 57-8). In "Morning in the Bowl of Night," the most hopeful of these stories, Alan realises that a relationship is a complicated mechanism of both positive and negative aspects and emotions and that evading the latter can effectively destroy it. "Love could be torn down in a minute, like taking a stick to a spider's web. But love was an admixture; it never came pure. He knew there was sufficient love and tenderness between them; and that no love should go wasted" (Kureishi 1999b: 205). Despite its occasional bleakness, Midnight All Day does confirm Kureishi's belief in love, which was so much embraced in his earlier works. Having been through crises, his heroes appear to have settled into their grown-up lives, ready to assume their responsibilities and make all necessary compromises.

\section{Confessions of an English Family Leaver}

The majority of critics and reviewers have considered Intimacy Kureishi's most apparently autobiographical work, if not a kind of autobiography. It reads like the confession of a man abandoning his family as he no longer finds living with his partner emotionally and physically bearable, yet it is, for many reasons, highly doubtful that Jay, the protagonist, represents Kureishi's alter-ego and is a mere mouthpiece of his creator's own worries and frustrations. A distinction needs to be made between autobiography and writing from experience, even though the dividing line can in some cases be very indistinct. Most writers of realistic fiction use their own experience to a certain extent in order to make their works authentic and convincing, but only a few of them have had their private life scrutinised at length in the media. As Kureishi's separation from Scoffield and their two young sons had previously been made a public affair in the press, Intimacy served as an easy target for those who wished to go on gibbeting him by denouncing the novella as another example of the author's heartlessness. Kureishi went through a parting that must have been immensely painful for both sides, primarily because of the children, and it naturally became a preoccupation of his writing since each creative process can bring a wished-for auto-therapeutic effect. However, instead of writing a spiteful testimony vindicating his act, he transformed his experience into an unconventional artistic project, which, understandably, can hardly be to everyone's liking. Therefore, to identify Jay as Kureishi and Susan as Scoffield means to assume a misleading perspective that considerably reduces the complexity of the text's narrative. Kureishi has repeatedly claimed that Intimacy is neither an autobiography nor a memoir but a fictional construct, a literary game. Kureishi's most articulate explanation of his true motives behind the novella can be found in the interview with Nahem Yousaf: in reaction to a question concerning the controversy around Intimacy Kureishi says:

I consciously wrote Intimacy in the form of a confession and was also aware that it might be read as "Hanif Kureishi telling the truth about a relationship 
break-up." That too is a literary construct: it is artificial. All of one's work is autobiographical to the extent that it reflects one's interests. But the book hasn't yet been read as a move in a literary game which is quite disappointing. It operates as a construct - written in the first person, constructed as a confession - and this is the basis on which it should begin to be evaluated. I wanted a book people would play with in that way. It is a text, not me. I am not the text. (2002: 25)

In other words, the text should not be read solely on the basis of an affinity with the author's life but rather as an organic continuation of his literary career, the next move in a literary game called "Hanif Kureishi's (semi-)fictional world."

In terms of genre, Intimacy represents the so-called confessional narrative or rather its specific variant of "male testimonial," a very popular form of fiction in British literature during the 1990s, and thus it belongs to other examples of the genre such as Will Self's Cock and Bull (1992), Nick Hornby's Fever Pitch (1992), Blake Morrison's And When Did You Last See Your Father? (1993), Fergal Keane's Letter to Daniel: Despatches from the Heart (1996) and Tony Parson's Man and Boy (1999). These narratives are constructed as confessional monologues laying bare and exploring various "private forms of masculinity" and "assertions of autonomy in the face of competing commitments to others" (Ranasinha 2002: 102-103) that are often discordant with society's expectations and demands, and therefore seen by many as a "manifestation of a contemporary 'crisis of masculinity' in a post-feminist era" (Moore-Gilbert 2001: 171). Although the genre concentrates on typically male preoccupations, its development owes much to feminism. Bart Moore-Gilbert notes Intimacy's parallelism with Doris Lessing's feminist classic, The Golden Notebook (1962), though he admits that the relationship is deeply ambivalent, arguing that Kureishi's novella is an "opportunistic appropriation of a 'subaltern' mode of writing by a member of the dominant gender to shore up challenges to its power" and "can be read as a reassertion of traditional forms of patriarchal masculinity"2.

Intimacy best exemplifies Kureishi's turn from broader socio-political issues to the constraints of relationships and family life seen from the male perspective, a confessional testimony that attempts to explore the formerly predominantly feminist territory of the politics of the personal. This shift from epic picaresque stories mixing the serious with the farcical is inevitably reflected in the form of the narrative, in the adoption of what Ranasinha terms "a new aesthetics" of wellobserved, inwardly-focused stories "closer to dramatic monologues than fiction," attempting to capture the "tumultuous drama of the domestic" (2002: 105-106), and, as Thomas relates, calling for "more experimental forms, and a more economical use of language" (2005: 134). The language and style of the short stories and, above all, of the novella is lucid and intelligible, highly disciplined, concentrated and with a clarity and intensity "sometimes bordering on the claustrophobic" (Ranasinha 2002: 107). This narrative form allows the text to reflect the narrator's mind - it is in places incoherent, fragmented, discontinuous, skipping 
from one subject to another, changing mood and often leaving ideas unsaid, questions unanswered and problems unresolved. Its effect lies in the insistence with which it forces the reader to follow the narrator's disturbed mind, to share the intimacy of his affection. As Kureishi explains:

I am much more interested in a piece of writing that is broken up, fragmented, unfinished. [...] I liked Intimacy being a rough book in that sense; the cruelty, the fragmentation, the lack of smoothing out or over. [...] I wanted the book to be an experience. If I wrote a book now about a relationship that split up ten years ago, it would probably be overworked and too thought-out. I wanted to capture the roughness. The style you use has to reflect what is going on in the mind at the time of writing. (Yousaf 2002: 22)

Intimacy aims at manufacturing the texture of the narrator's frustrated psychological states and the thoughts and sentiments these invoke, no matter how disagreeable they are, in the form of a raw narrative that grabs hold of its readers and does not let them go. One possible answer to the autobiography/fiction question can thus be formulated as follows: the novella is autobiographic in the sense that readers can experience the writer's frame of mind and that the text forces them to attune themselves to his present mental wavelength. Whether the ideas presented in the book are Kureishi's own is open to debate; what is guaranteed, however, is that Jay's psychic disposition is by no means alien to Kureishi as it is deeply rooted in his life experience.

\section{On the Move Doing Nothing}

The central reason why it is hard to believe that Intimacy's narrator represents its author is the alienation effect Kureishi evokes in readers by his permanent keeping of an ironic distance from Jay's self-exposure and self-questioning (the title itself is an act of irony compared to the originally conceived Animosity). Kureishi makes him an immature, contrary and self-indulgent character whose personality lacks integrity and a capacity for loyalty. He longs for love, a "perpetual child, a man who has convinced himself that his fear of life's depths is actually a passion for its summits" (Miller 1999). Kureishi lets his protagonist reveal his true character bluntly on several occasions. When explaining why he has not married the mother of his two sons Jay reveals a great deal of malicious vengefulness and bitter hostility towards Susan, as if staying with her was not his own decision but a kind of punishment inflicted on him by some external authority: "Certainly I enjoyed making her the only unmarried woman in her group of friends from university. She learned that her love involved sacrifice" (Kureishi 1998: 72), a ridiculous statement from someone who does not even understand what it means to make a concession in a relationship. When asking himself if he has tried hard enough to save the family he admits he has been a "morose, over-sensitive, 
self-absorbed fool" (Kureishi 1998: 80), too lazy and indolent when it comes to household duties. Readers can imagine how difficult living with Jay must have been when even Nina, his young girlfriend who seems to provide him with everything he has been denied by Susan, calls him an inflexible tyrant (Kureishi 1998: 81). Moreover, Kureishi puts into his narrator's mouth statements that can hardly gain any sympathy from readers as they are overtly childish, aggressive, sexist, intolerant and misogynist. For instance, having reduced women to a source of carnal pleasure he compares his interest in women to lifting up girls' skirts (Kureishi 1998: 18-19); when watching his friend's serene wife he feels a hateful urge "to kiss her and push her into the bedroom, thereby, it seemed to me, smashing everything up, or testing it, or trying to see what was there, what the secret was" (Kureishi 1998: 40); sometimes his ideas are simply inconsiderate, unthinking or even utterly stupid, as in the case of his conclusion on the dilemma concerning the ethics of leaving one's family: "But I could only think that there are some fucks for which a person would have their partner and children drown in a freezing sea. My kingdom for a come" (Kureishi 1998: 120), when calling his unhappy mother an obese "lump of living death" (Kureishi 1998: 59), or in his Henry Miller-like macho quasi-aphorism: "How do I like to write? With a soft pencil and a hard dick - not the other way round" (Kureishi 1998: 62).

On the one hand, Kureishi makes his narrator's frankness so disarming that one would almost take him for a victim and feel for his hurt self-pity, but, on the other hand, he deliberately makes his statements so inconsistent and contradictory that they in effect deny what they are meant to declare. Not far from the beginning of his narrative Jay recalls how, as a teenager, he tore the Thom Gunn poem "On the Move" from a book, declaiming it at parties, taking its last line, "One is always nearer by not keeping still," as his life motto, but only a few pages later he admits that soon he "figured that doing nothing was often the best way of doing something" (Kureishi 1998: 53), an attitude to life he more likely seems to have endorsed. While he sees himself as a kind of willing outlaw, always on the move, knowing that, in Gunn's words, there is "Reaching no absolute, in which to rest," in reality he longs for a peaceful and contented life: "If only I could sit here contentedly in the middle of my life as children seem to in theirs, without constantly worrying about the state of things, tomorrow, next week, next year. [...] I can't bear it when things go slack, when there isn't sufficient intensity. But I would welcome a quiet period. I am hoping for that, in the long run" (Kureishi 1998: 129). Jay's obsession with moving is one of the book's central ironies, hence the Gunn poem from the collection The Sense of Movement (1957) on the one hand, and his repeated admissions of passivity and evasiveness, implying not only that running away is his way of facing a discomfort, but also that his doing nothing is in fact one of the causes of things going slack on the other. Jay's mockery is complete when confronted with his friend Asif's idea of true love - having heard Jay complaining that he cannot "move" at home, Asif notes that "with a real love there is little movement. You are going round and round, but further and further" (Kureishi 1998: 132), an inconvenient truth to which Jay finds no response. 
"You can, of course, experiment with your own life. Maybe you shouldn't do it with other people's" (Kureishi 1998: 50) says Jay and, as in many other cases, it is easy to agree with him as long as his ideas are taken out of context. He has turned his life into an experimental pursuit of pleasure, which, thanks to his egotism, emotional liability and tendency to self-pity, inevitably causes not only his frustration but also other people's misery. What he suffers from is the absence of a balanced, mature personality although he keeps struggling to conceal it in his (quasi-)apologetic polemics, and he makes use of his relationships to create a wished-for identity and at least for some time to maintain this illusion. The desire for a new identity is also one of his crucial reasons for leaving his family: "I am not leaving this unhappy Eden only because I dislike it, but because I want to become someone else" (Kureishi 1998: 101), a wish one would rather expect from an insecure teenager than from a middle-aged father of two children.

Kureishi deliberately distances himself from his narrator by showing the various discrepancies between what he says and what he does. Ironically enough, Jay's central argument is that he wishes, for a change, to be more himself: "I have integrity too, I am sure of it. It is difficult to explain. [...] I suppose I want to be loyal to something else now. Or someone else. Yes; myself" (Kureishi 1998: 42). However, the statement contains two inconsistencies at once: first, it suggests that so far he has led an altruistic life full of sacrifices for other people; second, it indicates that loyalty ranks among his strong character traits. Neither of these, of course, is true as he has always entered and left relationships for the selfish reasons of a pleasure-seeker and has elevated unfaithfulness almost to a virtue and leading principle of his life. Jay contradicts himself even in terms of his favourite theme - the fear of losing himself within the pressures of a relationship: "We want love but we don't want to lose ourselves" (Kureishi 1998: 125). In his case, however, this means to be hidden securely in the shell of his egotism, passivity and indifference. When he says that "nothing is as fascinating as love, unfortunately" (Kureishi 1998: 94), he merely expresses his regret that love involves both giving and receiving. Theoretically he has it mastered: "I know love is dark work; you have to get your hands dirty. If you hold back, nothing interesting happens. At the same time, you have to find the right distance between people" (Kureishi 1998: 94), while practically he is washing his hands as thoroughly as possible. To demonstrate his ability to commit he remembers, as is usual when looking for an excuse for his immature behaviour, the good old days of his youth: "In the late sixties and seventies I did feel that I belonged to something, to other young people, and to some sort of oppositional movement. The earnestness I disliked; I was too awkward to join things. But there is something I miss: losing oneself, yes, in a larger cause" (Kureishi 1998: 146), but does not realise that more than any sincere belonging to a larger cause it points to his typically non-committal stance of always going with the flow, "losing himself" only as long as it does not endanger his comfort.

In The Art of Life (2008), Zygmunt Bauman analyses the role and understanding of happiness in contemporary western society. Our individualised, hyper- 
consumerist society has replaced happiness as a lasting state with a continual pursuit, in other words, permanence has given way to transience and temporariness, "a new restlessness about" (Kureishi 1998: 131) as Jay calls it. The problem is that in a world that offers instant pleasures and passive entertainment the price for any long-lasting engagement, including love, appears to be a too risky an investment, with little or no guarantee of profit. Bauman notes that people have ceased to recognise the obligation to live for something other than themselves. The art of life, Bauman concludes, is to find the courage and willingness to make sacrifices and show loyalty towards others in order to achieve happiness as a state to be maintained and cultivated rather than seeing it as a changing station on a never-ending journey ${ }^{3}$. Jay is a perfect example of such a perpetuallydeprived postmodern happiness-seeker - although he acknowledges life as an art, his definition is at odds with Bauman's: "If living is an art it is a strange one, an art of everything, and particularly of spirited pleasure" (Kureishi 1998: 63), preferring momentary satisfaction to the uncertainty of firm bonds. Kureishi is not a sociologist, but what Bauman formulates in scholarly terms he gives life to and exemplifies in Intimacy, namely the futility of the search for love without commitment. Even Jay's life credo, "I believe in individualism, in sensualism, and in creative idleness. I like the human imagination: its delicacy, its brutal aggressive energy, its profundity, its power to transform the material world into art" (Kureishi 1998: 132), shows only one side of the coin, which proves insufficient in preserving love in any long-term perspective as it lacks what Ivan Klima (1999: 62) finds crucial when he compares love to the creation of the work of art: the "constant attention to one's partner's intrinsic nature, an effort to comprehend his or her individuality, and respect" and "tolerance, the awareness that one must not impose one's outlook or ideals on one's companion or stand in the way of the other's happiness." Like Bauman, Kureishi leaves the ending of his book open his protagonist knows what he wants and how to achieve it but whether he "will survive the knowledge and put it to good use - whether any of us will - is another matter" (Kureishi 1998: 152).

\section{The Necessity of Satisfying Oneself}

The most frequent object of Jay's contemplations and the greatest target of his verbal assaults is his soon-to-be ex-partner Susan. Although he strives to portray her negatively as a cold, emotionless woman with little or no consideration of his needs and desires, the effect is quite the opposite - instead of demonising Susan he only manages to further discredit himself. Once again, Kureishi lets Jay contradict himself in the very essence of his reasoning. On the one hand, he depicts her as an "effective, organized woman" (Kureishi 1998: 28), who "doesn't constantly lucubrate on the splendours and depths of her mind. [...] But to keep everything going she can be bullying and strict, with a hard, charmless carapace" (Kureishi 1998: 30-31), but, on the other hand, he admits that it was precisely this quality he 
found attractive about her at the beginning of their relationship: "There was never great passion [...] But there was enjoyment. Mostly I liked her humdrum dexterity and ability to cope. She wasn't helpless before the world, as I felt myself to be. $[\ldots]$ At the expense of feeling weak, I enable her to feel strong. If I were too strong and capable, I wouldn't need her, and we would have to part" (Kureishi 1998: 29-30). This statement suggests his exploitative psychic dependency on Susan. She once possibly viewed this as charming but, unaltered as it remained, she grew understandably resentful of it. Therefore, when he complains that his behaviour infuriates and frustrates her but does not know what he should do to stop her being angry, he merely underlines his ultimate helplessness and resignation when facing the most common demands of family life. However, Jay's puzzled remark: "She envies my insouciance, I think. What other function I serve I am not sure, though I have always been urgently required by her" (Kureishi 1998: 31) shows he is, subconsciously at least, aware of the real state of affairs.

This suspicion is later confirmed when Jay concedes that Susan has in fact never been cross with him without a well-justified reason: "I can't say that Susan has ever deliberately let me down or been more gratuitously cruel than necessary with someone as recalcitrant as me" (Kureishi 1998: 100). Moreover, what also appears to irritate him is the fact that she can precisely identify and formulate his "diagnosis":

Susan [...] thinks we live in a selfish age. She talks of a Thatcherism of the soul that imagines that people are not dependent on one another. In love, these days, it is a free market; browse and buy, pick and choose, rent and reject, as you like. [...] Susan would say that we require other social forms. What are they? Probably the unpleasant ones: duty, sacrifice, obligation to others, self-discipline. (Kureishi 1998: 68-9)

Seeing partnership principally as a kind of business enterprise where the aim is to make big profits with minimum costs and investments is a poignant metaphor with which sociological thinkers of the postmodern era like Bauman, Anthony Giddens or Gilles Lipovetsky would hardly disagree. Jay's explanation of his pathological aversion to these "unpleasant social forms," on the contrary, is far less convincing. He claims that he simply belongs to an explicitly irresponsible and hedonistic generation growing up and maturing in the late 1960s and 1970s, one that no longer felt the need to fight for radical changes like their immediate predecessors, and thus instead of political or social commitment they believed "in the necessity of satisfying oneself" (Kureishi 1998: 79):

Between the deprivation of the post-war slump, and the cruelties of the eighties, we were the children of innocent consumerism and the inheritors of the freedoms won by our seditious elders in the sixties. [...] We weren't much restrained by morality or religion. Music, dancing and conscienceless fucking were our totems. (Kureishi 1998: 69) 
All this, however, applies almost without exception to men as women occupy a specific position within Jay's theory since, unlike men, they still had much to fight for in the 1970s, and therefore could not afford to become as self-indulgent as their male counterparts.

The women, I think, were fortunate to go in two directions at once, into themselves and out into the history of the world. They examined their lives more than we did; they experimented; the interesting ones changed more than we did. What is left? The freedoms Nina takes for granted, a free girl swinging about the city. All is absorbed. (Kureishi 1998: 71)

Rather than a credible explication of a certain sociological observation it sounds more like the peevish sigh of a man who went on a fifteen-year spree and when he comes back and eventually sobers up he finds out with amazement that his wife has changed in the meantime. As usual, Jay is caught in the clash between what he feels he should theoretically do and what he is practically capable of. Although, from the example of his parents, he knows that patriarchal social arrangements are oppressive and functionless, making both partners frustrated, he finds himself helpless in relationships with independent, self-sufficient women as he no longer knows what his role in them should be. The argument that in the past it was easier for men to be loyal to their wives because they "had the power and had to be protective" (Kureishi 1998: 56), which at least represented some certainty, a firm social obligation that made leaving the family more problematic, contains an inherent nostalgia for the orderly patriarchal old days. Therefore, when he calls Susan disapproving and bad-tempered (Kureishi 1998: 103) he only disguises his own disapproval and bad temper arising from the frustration of a man unable to find his place in a society undergoing inevitable transformations.

\section{The Worlds and Worlds and Worlds Inside Us}

Apart from the inwardly focused confessional testimony of the narrator Intimacy also muses on some of the themes of Kureishi's previous works, the most crucial of these being creativity and imaginative activity, namely writing. Kureishi continues to explore the theme in Midnight All Day in which most of the protagonists have creative jobs and find creativity one of the most effective ways out of their crises. The theme then culminates in Gabriel's Gift which can be read as a paean to the power of human imagination and a creative attitude to life, claiming that nowadays only artists remain to provide spiritual guidance (Kureishi 2001: 161). Jay and Kureishi's male characters from the short stories might appear disagreeable, ridiculously vain, self-deceptive and regretful, yet when it comes to the theme of creativity they assume expressiveness and force, which is strikingly more convincing than their self-pitying and self-vindicating effusions. Therefore, when looking for Kureishi's autobiographic projections into his fiction, these in- 
stances likely represent his personal perspective because they also contain an outspoken artistic defence of his most controversial work.

Jay first touches on the theme when he ponders the importance of imagination: "The world is made from our imagination; our eyes enliven it, as our hands give it shape. Wanting makes it thrive; meaning is what you put in, not what you extract" (Kureishi 1998: 41). The idea that meaning is not an inert property but a process each person has to take an active part in sounds hardly contestable unless readers connect it with the speaker's attitude to life and his personality. When talking about creativity it is as if Jay suddenly becomes someone else, an authorial voice elucidating the very essence of his latest literary project: "I will be needing pens and paper on my journey. [...] I will pursue my feelings like a detective, looking for clues to the crime, writing as I read myself within. I want an absolute honesty that doesn't merely involve saying how awful one is" (Kureishi 1998: 62). Since it is almost impossible to imagine Jay making a strenuous effort to write a continuous text, the lines refer more to the author and the creative principle behind the narrative - by saying "writing as I read myself within" instead of "writing myself from within," Kureishi clearly refuses the purely autobiographic element in Intimacy in favour of the writing-from-experience perspective; moreover, the last sentence points to the text's possible trap of inciting readers to become moral judges rather than participants in a literary game exploring the ambivalent border between art and morality. Kureishi ironically uses Asif, Jay's antipode as far as fidelity and integrity are concerned, in this argument: "But Asif's favourite opera is Don Giovanni, and Anna Karenina and Madame Bovary his favourite novels. Testaments of fire and betrayal, all!" (Kureishi 1998: 44), observes Jay triumphantly as if he has just disclosed his friend's hideous double personality. In the larger context of the novella, Kureishi seems to place the ineptitude of this logic next to that linking his personality automatically with his fictional creation.

Kureishi follows up on this argumentation in Midnight All Day, which can partly be read as the author's response to the largely hostile critical reception of Intimacy. In "Strangers When We Meet," the only story in the collection to use a first-person narration, Rob, the narrator, mentions an experience whose relevance to the actual atmosphere around the publication of the novella is more than evident: "I have been reading an account by a contemporary of his break up with his partner. It is relentless, and, probably because it rings true, has been taken exception to" (Kureishi 1999b: 48). In "That Was Then," Nick, the story's protagonist, is a recognised writer who meets his ex-girlfriend, Natasha, who feels betrayed and exploited by his having used her as a model for a not very positively portrayed female character in one of his novels. The situation echoes that of Intimacy, this time concerning Scoffield's alleged affinity with Susan - Natasha accuses Nick of expedience, vengefulness, misogyny and abuse of a writer's omnipotence. Nick at first tries to explain that the main aim and potential of fiction is not to portray real people as they are but to capture, more authentically than other media, what might be going on in the characters' minds, which is always more successful when based on one's own experience. When she still asks why 
he did not depict her personality in its complexity his answer is very plain - she is not the character portrayed: "I took the parts of you I needed to make my book. It wasn't a fair or final judgement but a practical transformation, in order to say something. Someone in a piece of fiction is a dream figure ... picked from one context and thrust into another, to serve some purpose. A tiny portion of them is used" (Kureishi 1999b: 85). Although it is understandable that even this tiny portion can be resented by those who partly identify themselves in the fictional protagonists, it is a legitimate, though sometimes morally ambivalent, artistic method and as such it should be judged: successful and convincing or bad and artificial. Susan is not Scoffield, just as Jay is not Kureishi, however, whether Jay's feelings and moods to some extent reflect Kureishi's own is another matter. At the end of "That Was Then," Nick is thinking about what he should have said to Natasha: "There are worlds and worlds and worlds inside you.' But perhaps it wouldn't mean anything to her" (Kureishi 1999b: 91). This seems to be Kureishi's last contribution to his in-fiction defence of Intimacy - it attempts to depict one of these worlds as honestly and suggestively as possible without adopting any moral attitude towards it.

\section{The Art of the Broken Side of Things}

Kureishi has always been an unconventional writer "interested in challenging orthodoxies" (Brownrigg 1999) and Intimacy is no exception, though the conventions violated in the novella differ from those in his previous works. He assumes the role of a psychoanalyst recording the sincere confessions of his patient with the minutest precision. The patient is a middle-aged man about to leave his partner and two children, an essential anti-hero hard to identify with, and Kureishi portrays him as such. The narrative's "brilliance lies in Kureishi's ability to allow the reader total empathy with but almost no sympathy for his protagonist" (Rance 2010). The ravishing honesty of this monologue, which juxtaposes Jay's numerous flaws with his panic at losing his children, fear for the future, admiration of Susan's enthusiasm for their children or seeing his inability to love her as exclusively his failure, asks readers to abstain from moral judgment and let the stream of his often inconsistent emotions and thoughts flow over them freely. "To choose someone is to uncover a whole life. And it is to invite them to uncover you!" (Kureishi 1998: 20), says Jay, and Kureishi invites his readers to uncover one of the countless worlds inside the minds of certain men in certain critical life situations. The text describes not prescribes; it portrays one form of contemporary masculinity yet remains far from promoting it. It is easy to reprobate Jay as cowardly and irresponsible but Kureishi provokingly suggests the existence of a counter-perspective, seeing Jay as one who did find the "will, courage or sense of duty" (Kureishi 1998: 45) to undergo a highly unpopular and socially deprecated step. By deliberately giving voice to only one side of the conflict, Intimacy represents an "essentially imaginative "falling-out-of-love book" (Moore-Gilbert 
2001: 16) attempting to narrativise the old truth that separation is always painful, that there is never a right time for a break-up, just as there is never an unequivocal guilty party. An outsider is never able to fully understand the mechanisms of another's relationship and hence his/her role is inevitably reduced to that of a listener/observer. Kureishi admits his fascination with "what is self-destructive in human life" (Buchanan 2007: 118) and Intimacy exposes its readers to the very texture of this tendency.

Intimacy, though not large in scope, is undoubtedly an ambivalent book namely because it invites a great variety of readings. Buchanan (2007) offers the perspectives of Oedipal motifs of maternal lovers, male infantilisation and girlwoman sexual fantasy figures (37-38) and the internal mechanics of race (74-76) and class (82-83) dynamics in the family. Ranasinha (2002: 110-111) suggests it could be understood as pure irony and a satire on male narcissism, selfishness, cruelty and immaturity were it not for the narrator's self-awareness, thanks to which the novella both parodies and exonerates a whole generation of men like Jay. Moore-Gilbert shows that it can be read as both critique and endorsement of patriarchal attitudes (2001: 156-157), or as a specific reaction to certain "post-feminist" works, partly corroborating their criticism of feminism "from the point of view of its failure to register sufficiently some of the consequences of the Women's Movement's successes for contemporary men" (179). It may also be what Rance calls "the beautifully ambiguous genre of fictive autobiography" (2010). At a basic level, then, it can be read as a text hostile to women or even misogynist, an example of so-called "prick-lit," a genre which presents an unconventional introspection of male sexuality as essentially amoral, lustful and aggressive and thus separated from love or affection (Hari 2009), or as a malevolent reprisal directed against the author's ex-partner. Although all these perspectives are legitimate and provide interesting analyses of the story, the fundamental intention behind the book seems to be found elsewhere, in a "dramatization of that sadly familiar mechanism that demonizes the object of rejection to make the leave-taking less painful and justify the otherwise morally dubious action" (Proctor 1999). In consonance with Kundera's persuasion that the aim of a novelist is to "draw up the map of existence by discovering this or that human possibility" (Kundera 2005: 43), Intimacy explores one such possibility - it may be a particularly unpleasant and uncomfortable one, but Kureishi demonstrates that humanity comprises such "contribution(s) to the broken side of things" (Kureishi 1998: 134) as well. As Buchanan puts it:

Kureishi's fiction attempts to show us that seeing human beings at their worst does not mean that we are seeing humanism at its weakest; on the contrary, where complex people such as Kureishi's are displayed at their least attractive, we are forced to recognize the many traits we share with them and consider the degree to which we share their degradation. It is not a pleasant prospect, but to refuse to face it is, in Kureishi's view, a failure of the mind, heart and imagination. (2007: 164) 
Knowing the context of Kureishi's life it is indeed difficult to avoid a personal or biographic reading of Intimacy, yet abandoning this interpretative framework opens a new possibility of reading it - as a peculiar and distinctive account of what it also takes to be a human being. To ignore this perspective, Kureishi implies, would be hypocritical. Despicable as Jay can be, his awareness of and belief in the possibilities of love hold some naked hope for us all in that even he might eventually overcome the barrier of inert self-centredness and find what he is looking for. "That we end up feeling sorry for no one, sensing that everyone may actually be better off someday, whether the characters seem to deserve it or not" (Proctor 1999) is, after all, quite a decent prospect for a book beginning as the narrator's saddest night.

\section{Notes}

1 Kureishi even transformed this genre onstage in the play Sleep With Me (1999), see Ranasinha (2002: 102-103).

2 For further information see Moore-Gilbert's analysis of Intimacy from a feminist perspective, pp. 173-175.

3 Bauman deals with this theme in detail in the chapters "Miseries of Happiness" and "We, the Artists of Life," pp. 21-92.

\section{References}

Bauman, Zygmunt (2008) The Art of Life. Cambridge: Polity Press.

Brownrigg, Sylvia (1999) 'High Infidelity: An Interview with Hanif Kureishi'. Sylviabrownrigg. com. 26 May 2010. <http://www.sylviabrownrigg.com/Reviews/interview-voice-kureishi.htm>.

Buchanan, Bradley (2007) Hanif Kureishi. Basingstoke: Palgrave Macmillan.

Hari, Johann (2009) 'Hanif Kureishi on the couch' (interview). The Independent. 2 February 2009. 26 May 2010. <http://www.independent.co.uk/arts-entertainment/books/features/hanif-kureishion-the-couch-1522837.html>.

Klima, Ivan (1999) Between Security and Insecurity. London: Thames and Hudson.

Kundera, Milan (2005 [1988]) The Art of the Novel. London: Faber and Faber.

Kureishi, Hanif (2002) The Body. London: Faber and Faber.

Kureishi, Hanif (2001) Gabriel's Gift. London: Faber and Faber.

Kureishi, Hanif (1998) Intimacy. London: Faber and Faber.

Kureishi, Hanif (1999a [1997]) Love in a Blue Time. New York: Simon \& Schuster.

Kureishi, Hanif (1999b) Midnight All Day. London: Faber and Faber.

Kureishi, Yasmin (2008) 'Keep Me Out of Your Novels: Hanif Kureishi's Sister Has Had Enough'. The Independent. 4 March 2008. 26 May 2010. <http://www.independent.co.uk/ arts-entertainment/books/features/keep-me-out-of-your-novels-hanif-kureishis-sister-has-hadenough-790839.html>.

Miller, Laura (1999) ‘Intimacy’ (Review). Salon.com. 3 March 1999. 26 May 2010. <http://www. salon.com/books/review/1999/03/03/sneaks>.

Moore-Gilbert, Bart (2001) Hanif Kureishi. Manchester: Manchester University Press.

Proctor, Minna (1999) 'Buddha Leaves Suburbia' (Review). The Nation. 1 April 1999. 26 May 2010. http://www.thenation.com/article/buddha-leaves-suburbia>. 
Ranasinha, Ruvani (2002) Hanif Kureishi. Devon: Northcote House.

Rance, Polly (2010) 'Intimacy' (Review). The Richmond Review. 26 May 2010. <http://www.richmondreview.co.uk/books/intimacy.html>.

Thomas, Susie (ed.) (2005) Hanif Kureishi. Basingstoke: Palgrave Macmillan.

Yousaf, Nahem (2002) Hanif Kureishi's The Buddha of Suburbia. New York, London: Continuum.

Petr Chalupský is currently the Head of the Department of English Language and Literature at the Faculty of Education, Charles University, Prague, where he teaches English Literature, Literary Studies and Literary Theory. He has published articles in journals and conference proceedings, e.g. "Crime Narratives in Peter Ackroyd's Historiographic Metafictions" in European Journal of English Studies (Routledge, 2010) and "The Urban Pastoral - Hybridisations in Jim Crace's Arcadia" in Litteraria Pragensia, 20.40 (2010), and contributed to Literary Childhoods: Growing Up in British and American Literature (University of Pardubice, 2008). In 2009 he published a monograph The Postmodern City of Dreadful Night: The Image of the City in the Works of Martin Amis and Ian McEwan.

Address: Dr. Petr Chalupský, Department of English Language and Literature, Faculty of Education, Charles University, Celená 13, 11639 Praha, Czech Republic. [petr.chalupsky@pedf.cuni.cz] 
